\title{
Continuing Education During Times of War: Experiences of Children in Northern Sri Lanka
}

\section{ESJ Humanities}

\section{Iresha M. Lakshman}

(Associate Professor, PhD)

University of Colombo, Sri Lanka

\section{Rajeswaran Rajeshkannan \\ (Senior Lecturer, MPhil)}

University of Jaffna, Sri Lanka

\section{Mark Schubert}

(Researcher, BA)

Social Scientists` Association, Sri Lanka

Submitted: 19 October 2020

Accepted: 02 December 2020

Published: 31 December 2020

Corresponding author:

Iresha M. Lakshman

DOI: 10.19044/esj.2020.v16n35p1

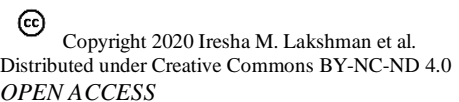

OPEN ACCESS

\begin{abstract}
The primary objective of the study was to explore the experiences of children during and after 30 years of civil war with particular attention on its impact on their academic learning. The research intended to answer two research questions, namely 1) How did the war impact on children's education? and 2) What support networks were available for children affected by war to remain in school and/or to continuously engage in academic learning? The research was carried out in the Jaffna District of Northern Sri Lanka and depended entirely on qualitative data generated through in-depth interviews, key informant interviews, focus groups discussions and observations. Multiple displacements caused by war, the impact of war on livelihoods and the trauma caused by war has resulted in some students losing interest in school and eventually dropping out. In spite of various financial and other support provided by local and international NGOs only some children have remained in school with a sustained interest in education. A characteristic common to these children was that they came from more 'secure' family backgrounds. The security offered by intimate relationships within the family seems crucial for educational success even during times of war. The findings suggest the need for strengthening family well-being and stronger emotional support to ensure sustained interest in education during times of war.
\end{abstract}

Keywords: Sri Lanka, civil war, education, social capital, family 


\section{Introduction}

Thirty years of war in Sri Lanka has destroyed the country's physical infrastructure and harmed human life leaving many families in IDP (Internally Displaced Persons) camps. Northern and the Eastern parts of the country has been the worst affected by war. In the context of war, children and women are usually identified as vulnerable groups whose security is likely to become more fragile than other members of the same affected society (McKay, 2004; Onyango, et al., 2005; Somasundaram, 1998; Tolin \& Foa, 2006). In the case of children, their education, measured through school attendance and acievements at examinations, is a key area in which their rights are likely to be violated.

Keeping children in school during times when their mere survival is threatened, would firstly require that their basic needs such as food, health and shelter are adequately fulfilled. Secondly, social and psychological wellbeing of children would be essential to ensure that their interest in education is sustained, because education is likely to be pushed away if these primary needs are not fulfilled. The current study proposes to examine the impact of war on children's education by examining 1) the nature of its impact on children's education and 2) the kinds of support networks available for students to remain in school with their interest in education intact.

The research was carried out in the Jaffna District of Northern Sri Lanka, one area worst affected by 30 years of civil war. Data collection was done mainly in two Divisional Secretariat Divisions (DSD), namely Vadamaradchy North and Valikamam North. Coastal villages in Point Pedro in the Vadamaradchy North DSD, Thumpalai, Punidhanagar and an IDP camp in Polikandy were studied. Fisheries villages in the Madhagal Coastal area and two IDP camps in Valikamam North were also selected for data collection. In Kankasanthurai, the staff and Principal of a school that was moved to another area during the war and resettled back in its original place in 2017 were also interviewed. An observational visit was also made in the Vadamaradchy East DSD gaining the opportunity to speak to few villagers from Maruthamkerny and some officials at the Divisional Secretariat (DS) office.

The study depended entirely on qualitative data generated through indepth interviews, key informant interviews, focus groups discussions and observations. Key informant interviews were conducted with authorities in the DS offices of the respective DSDs, zonal education officers and local politicians while focus group discussions were conducted with community leaders, social workers and villagers. In-depth interviews were conducted with women leaders and members of the community. In total a sample of 16 Government officials and Politicians, 20 villagers (men and women) and 11 social workers were interviewed during the study. 


\section{Impact of war on education}

Being one of the first locations to have established missionary schools during the time of the British, people of the Jaffna peninsula, particularly the Vellalas, has always been known for a keen interest in education shown by its people (Sivakumar, 1989). The American missionaries also have contributed towards developing a strong educational base in Jaffna and opened up educational opportunities to many across caste and gender differences (Arunthavarajah, 2013). History records a steady stream of lawyers, teachers, doctors and civil servants from the Jaffna peninsula (Spencer, 2002).

However, possibilities of educational opportunities available to people are likely to be restricted by institutionalized social stratification structures, i.e. the class, caste and gender make-up of the people in the region (Lall, 2016).

Traditional social stratification structures of other regions in the country also has had a similar influence on educational opportunities available to individuals or groups. However, several decades of education, awareness, human rights movements and social protests for equality has contributed towards improving the situation in these other regions opening up more and newer opportunities for education irrespective of the social status quo. In Jaffna, the war delayed this kind of progress by about 30 years. The war slowed down socio-economic development of the region in several ways; namely death, disability, psychological trauma, displacement of several thousands of people, destruction of physical assets and outward migration of educated Tamil (Somasundaram, 1998). During the current study several respondents mentioned how the general standards of education in the area has dropped as a result of war.

Everybody is shouting that the North has gone down in education. This weakening of the education levels in Jaffna has been created by 30 years of war. Between 1983 and 1995, the cream of Jaffna left the country. 40 years ago, there were 25 piano teachers in Jaffna. Now, no one.

- Provincial-level politician -

The same view was expressed by a group of local elites during a focus group discussion in Point Pedro. The war has also contributed towards changing the traditional make-up of the educational institution in Northern Sri Lanka.

Poverty, lack of parental attention, alcoholism and low education levels of mothers play a crucial role in educational levels. IDPs who are the lowest in the social strata of the area face even bigger challenges. Earlier there were some elitist schools in Jaffna attended only by certain upper classes. During the war many of these families either migrated to the South seeking city schools or to foreign countries breaking the elitist identity of the schools. Now schools are attended by people from all walks of life.

- Provincial-level politician - 
The same view was shared by several other government officials. These respondents believed that the shift in the elitist identity of some schools also resulted in a deterioration of education in general in the province. However, a social worker had a different interpretation about this shift in school identity. She pointed out that this shift in the elitist identity of some schools opened up educational avenues for academically inclined children from marginalized castes in the region as a result of LTTE (Liberation Tigers of Tamil Ealam) policies.

War is essentially a tragic and shocking experience for all citizens living in the concerned country/ countries. In the case of children, the impact of war can be particularly adverse given the fact that they are unable to fully comprehend the things that are happening around them. The impact of war on children could last even after the end of war resulting in long term shock (Akresh, Verwimp \& Bundervoet, 2011; Boyden, 2003; Carpenter, 2005 \& 2006). In addition to more than half of civilians that are killed due to war being children, they are made victims of war through several other means as well; child soldiers, internally displaced children, sexual assault and exploitation of girls (Hick, 2001).

Compared to the above kind of life-threatening adversities, the impact of war on children's education can be considered to be at a lower level of adversity. However, as in the case of trauma caused by war, the disruption of education will have long term impacts on the individual as well as the country. Civil wars damage the education system of a nation in two ways: 1 ) by loss of infrastructure and personnel; (2) by drawing funds into military activities rather than education (Lai \& Clayton, 2007). National security and education are complementary factors that have been identified as vital in promoting national development. Therefore, children's right for education is stressed as a factor vital for a country's development (Shizha, 2017).

This perception echoed in the comments shared by most of the respondents interviewed during the study. None of the respondents interviewed during the study spoke of war having a 'direct' impact on the education of children in their community because they did not identify schools, teachers and students as direct targets of war. Damage to school infrastructure, death and immigration of people were discussed as having a secondary impact on education. The Government nor the LTTE were blamed for 'targeting' the schools or children's education during the battles. The issue of national funds been drawn from education to feed military activities, a more 'direct' impact, was not mentioned by any.

In spite of the negative 'secondary' impacts on education caused by war, the villagers did not identify the war as a situation that disrupted their educational opportunities. Rather, war was perceived as having 'restricted' their educational opportunities. During an FGD with village elites in Point 
Pedro, individuals revealed the difficulties they and/or their children encountered as students. However, many had persevered in education.

The Girls' School had a bunker to protect students during shell attacks. Eventually when the war aggravated it was moved to another school. There, students studied in temporary huts. We had bunkers in our houses and we studied inside them, sometimes someone used to peddle a bike and light up using a dynamo so that we could read... Children were anxious about going to school during this time. Some children dropped out. Parents sat in schools while their children studied.

- FGD in Point Pedro -

Even those who joined the LTTE as child cardre and were directly involved in the war do not blame the war for disrupting their education. On the contrary, one woman said that she was allowed to go to school and study while being a LTTE child soldier ${ }^{1}$.

I voluntarily joined the LTTE child cardres when I was 12. I was fascinated by the idea of being a soldier and went and joined. Because we were small, LTTE allowed us to go to school and study. But I dropped out of school. I left LTTE one year later. But my brother continued for 10 years and is now in a foreign country.

- Selvi, 40, Sinnathottam village ${ }^{2}$ -

In fact some villagers thought of displacement, the most commonly stated impact, as having had a positive impact on their education. Gowri, a school teacher with four siblings who are all employed in Government jobs or in foreign countries, thinks that the hardships of war motivated them to study.

We became good in our school work because of displacement. We lost everything including a permanent house when we got displaced. That is what motivated us to study hard.

- Gowri, 36, Madhagal -

As pointed out by the above historical context and the respondents, the war cannot be seen as 'entirely evil' when considering the education of children in Jaffna. The respondents saw the war as causing more 'secondary/ indirect' impacts on children's education through the displacement of individuals and schools, loss of livelihoods and loss of social networks due to death.

\section{Displacement of individuals}

All villagers interviewed had experienced multiple displacements during the war. For example, all 42 families who were living in an IDP camp

${ }^{1}$ There was only one former child soldier in the entire study sample, making it difficult to draw a concrete idea about this aspect of war.

${ }^{2}$ In citing statements by villagers, a fictitious name followed by real age and place of residence of the individual has been given at the end of the quote. 
visited during the study have been displaced at least three times during the war. In addition to the war, the 2004 tsunami has also displaced people forcing them into refugee camps. Masses of individuals were forced out of their villages within seconds during the war. The only possession these people have had were the clothes they were wearing at the time of fleeing. Though many people have continued education as IDPs, displacement has impacted children's education in several ways.

Some respondents, now in their 30 s or early 40 s, claimed that this kind of mass movement of people got young boys and girls fall in love with each other leading to early marriages that eventually stopped their education. Rajini, now 30 years old, has had just completed Year 9 in school when the war aggravated and students were asked to leave the hostel.

My education stopped because of war. It is not that the Army or the LTTE physically pulled me out of school. But the hostel closed down as the war worsened. Large numbers of people were displaced and fled to Maankulam. Many girls and boys fell in love during this journey. Me too. Then my mother insisted that I marry him.

- Rajini, 38, Point Pedro -

Irrespective of reason for displacement, whether war or tsunami, its impact on children's education was the same. It was seen as a reason that resulted in teenagers falling in love and getting married young resulting in dropping out of school. Similar findings have been recorded in other settings where conflict and displacements prevailed (Schlecht, Rowley \& Babirye, 2013).

Many respondents explained that parents saw marriage as a means to ensure the safety of their children during the war. In addition to providing the protection of a man for their daughters, marriage ensured that both young men and women would not be recruited forcefully as LTTE cadres (FGD with social workers). The same has been said about child marriages in conflict affected populations in Lebanon (Mourtada, Schlecht \& DeJong, 2017). Early marriage not only resulted in dropping out from school but destroyed future potential of the women as most of these marriages became abusive to women (Kottegoda, Samuel, \& Emmanuel, 2008; Lakshman, 2018).

As pointed out by Jayatilaka and Amirthalingam (2015), love marriages were encouraged by parents, mostly single mothers also as a way to get their daughters married without having to worry about a dowry.

My father died when I was very young. I studied up to Grade 8. Then I got married at 15. Without my father my mother couldn't manage the household expenses. That is why I dropped out and had to get married early. Because it was a love marriage, my mother didn't have to worry about.

- Lakshmi, 36, Punidhanagar - 
The following statement by a mother clearly shows the relationship between war and early marriage. Janani, a mother who had given away her eldest daughter in marriage at the age of 17 to a boy aged 18, now says that she wants to educate her youngest daughter who is 12 .

I too got married at 17. It was normal when we were young. I had to give my eldest daughter away in marriage at the same age in order to ensure their security against forced recruitment into LTTE. But now that there is no war, I do not want the same for my youngest daughter who is 12. I want to educate her as far as I can. She is also keen to study.

- Janani, 44, Point Pedro-

Rajini also had a similar comment to make about her daughter who is still in school. She said "First education, marriage later". This shift in attitude seems entirely caused by the end of war.

Another way in which displacement contributed towards dropping out of school was due to loss of school equipment (such as bags, uniforms etc.) and books during the fleeing. Research has shown inability to afford these education-related costs as a reason that obstruct the education of IDPs (AlKhalidi, Hoffman \& Tanner, 2007; Carillo 2009; Ensor, 2010). According to respondents in the present study, when children lost their books they eventually lost interest in studying and school, even when such facilities were provided in IDP camps.

Children lose interest in school when they lose all their school stuff, particularly the books. When we fled from our homes we just ran with nothing in our hands. Once settled in an IDP camp children received books, bags and shoes as donations. But that doesn't really help the children get back to school because their notes from the previous school is all lost. So children gradually lose interest in school and eventually drop out.

- FGD in Thellippalai -

\section{Displacement and temporary closure of schools}

In addition to displacing individuals and families, the war displaced schools as well. Nadeswara College in Kankasanthurai was once popularly known as school for children of elitist families representing high castes (refer previous quote from local politician). However, the school was displaced to Thellippalai in 1996 after the Kankasanthurai premises was taken by the Government for setting up a military camp. Schools being put to this kind of military use during war has been observed in other contexts as well (van Wessell \& van Hirtum, 2013) and it is sure to disrupt academic activities conducted in school. Once brought to Thellippalai, even though the academic activities continued in the new location, the social make-up of the school changed drastically. Large numbers of its original student population dropped and increasing numbers of children with low-caste identity from IDP camps entered the school. In June 2016, the school was resettled in its original 
location but by that time the composition of the student population and the social status attributed to the school has changed. Before displacement the school has had 3000 students, but in 2016 it had only $150^{3}$ students. Majority of these 150 students were from IDP camps (Director, Valikamam Zonal Education Office \& Coordinator, Chunnagam IDP camps). After its resettlement, the children who joined the school from IDP camps began facing financial difficulties of travelling to school as the bus fare is now much higher than what it was when the school was in Thellippalai. This is clearly an example of remnants of war impacting children's education even today. For example, Mary (war widow living in an IDP camp in Chunnagam) has three children attending this school and now the bus fare per day per child in Rupees 60. Given the current financial status of Mary's family the children are risking having to drop out from school. Continued existence of the High Security Zone run by the Government in the Kankasanthurai area which did not allow people to come back and resettle in these areas was another problem that impacted school enrollment.

It is meaningless to just resettle the school. We will not get any pupils if people are not allowed to come and resettle in their original homeland. We need people who will want to study in the school.

- Ganesh, Past pupil of Nadeshwara College in $2016^{4}$ -

The village school in Madhahal has also been displaced to Manipay during times when the war intensified. The original location of the school has been used as a navy camp. According to the Principal of the school, their problems now are far greater than the problem of war. People are gradually recovering from the war, but there are historically engraved problems in the community that are not so easily overcome. Poverty, low levels of education of parents, alcoholism and the recent prevalence of drug abuse were identified as determining the educational achievements of children now.

The war was seen to have caused temporary closure of schools during times when the war intensified. During such times it was unsafe to be on the roads traveling to schools. Similarly, temporary closure of schools occurred when refugee camps were set up in schools during the war.

\footnotetext{
${ }^{3}$ According to the school principal, there are only 102 students in the school now.

${ }^{4}$ The High Security Zone is now removed and people have been given access to their lands by now. Whether the situation has improved due to these new circumstances is not known.
} 
My eldest daughter lost about 3 months of school, during her scholarship exam ${ }^{5}$ year, as their school was used to house refugees. This may have caused her failure at the scholarship examination. But she later passed her $O / L^{6}$ and $A / L^{7}$ well. She got $3 A s^{8}$ for her A/Ls and is now hopeful of admission to Law Faculty. Other children's education was not disturbed by war. My second child also got through his O/Ls.

- Malar, 39, IDP camp -

Malar (39), a mother of five children was convinced that her other three children will also pass their O/Ls without any problem.

\section{Weakened financial and social capital due to loss of livelihoods}

Some individuals have had to drop out of school as a result of poverty that aggravated due to loss of livelihood and/or death of family members caused by war. Similar reasons for dropping out of school has been recorded elsewhere (Lakshman, 2018).

I was only two when I was first brought to an IDP camp. Of course I do not remember much. My family has been moving from one camp to another since then. My father died in 1990 due to war. We had no means of an income. Then my mother remarried someone she met in a camp. Later he too left her because the child born to them was severely disabled. My mother struggled to find work here in the camp. (Mother joins in) As children grow older school expenses also increase and I also had to look after my other daughter. I couldn't afford all this. So Anita had to drop out from school after passing Year 10.

- Anita, 28, Pulihandi ${ }^{9}$ camp -

War disrupted income opportunities resulting in an exacerbation of poverty (Amirthalingam \& Lakshman, 2012) which in turn led to dropping out of school. Severity of poverty in the region which affected education of children was explained using a unique example by some village elites in Point Pedro. According to them, people suffered so much in poverty to the extent that a bowl of porridge could attract them to school.

Children dropped out of school due to poverty which aggravated during severe conflict in the region. People didn't have enough to eat. NGOs gave porridge to school children and children actually came to school to eat.

- FGD in Point Pedro -

\footnotetext{
${ }^{5}$ National level examination held during the $5^{\text {th }}$ Year in school.

${ }^{6} \mathrm{O} / \mathrm{L}$ - General Certificate of Education (Ordinary Level) Examination is a national-level examination taken after 11 years of schooling.

${ }^{7}$ A/L- General Certificate of Education (Advanced Level) Examination is a national-level examination taken after 13 years of schooling. Results obtained at this examination determines a student's admission to a national university.

${ }^{8} \mathrm{An} \mathrm{A}$ is a distinction pass given to a student obtaining over $75 \%$ marks at both General Certificate in Education Ordinary Level (O/L) and Advanced Level (A/L) examinations.

${ }^{9}$ There are four IDP camps in Polikandi. The researcher visited only one of these camps. The camp visited is referred to as Polikandi camp without specifying the actual name or location of the camp.
} 
Explaining the nature of deprivation experienced by the people still in IDP camps, the coordinator of several camps in Chunnagam also explained that some children go to school for lunch. He added "We can't really blame parents for the lack of interest in their children's education. These people have been living under these stressful conditions for several decades now". He explained how the tin sheets on their houses in the camp heat up during the day and how that itself was stressful enough for people when it is an everyday thing. The positive relationship between income levels and education levels has been confirmed by many researchers working in different social settings (Jordan, Kaplan, Oláh \& Locuniak, 2006; Reay, 2006; Stinebrickner \& Stinebrickner, 2003).

In some cases children have dropped out of school due to lack of interest on the part of the child. Although the reasons behind this loss of interest was not always clearly stated, data suggests a combination of poverty and an interest in an early income either to support the family or to enjoy the pleasures of 'adult life' (see Willis, 1977).

The boys dropped out because they were simply not interested. None of them completed O/Ls. We sent them to school, but they went somewhere else and came home after school time. It wasn't war or poverty that pulled them out of school, they were just not interested. But now, thanks to the money they are earning, they are supporting their sisters to continue education.

- Revathy, 44, Sinnathottam -

War, displacement and poverty were all at work in discouraging education of those living in IDP camps. Some girls had to drop out of school and look after younger siblings in order to help parents engage in livelihoods. This is a common coping strategy repeated in literature on other regions of the country even under more peaceful circumstances (Baker, 1988; Little 1999).

I completed pre-school and Grade 1 in Palali, my home town. Then we came to this camp. I could study only up to Grade 5. But my brothers and sisters are better educated than me. One brother and one sister passed O/L. The youngest sister passed her A/Ls qualifying for College of Education. But she didn't go because of financial issues. They could study because I stayed at home and watched them while our parents were away working. There was no one to encourage me to stay in school.

- Sangeetha, 22, Polikandicamp -

No body helped us with our education. I went up to Year 9 and then dropped out in order to work and earn. I then looked after my brothers and sisters and educated them. During the war we went from camp to camp. The LTTE also started training their child cardres in our school grounds. Those were also reasons to drop out, but the main reason was family burden.

- Saroja, 34, Punidhanagar - 
During most of the interviews/FGDs with community-level leaders or elites, the case of the war widows was highlighted as a continuing challenge in the area. One form of supporting these women was the provision of livelihood opportunities (Gunatilaka \& Vithanagama, 2017; Lakshman, 2017). Thushita, a war-widow originally from a fisherman background explained the difficulties she encountered raising two children without a husband.

I was the eldest in my family. I had two brothers and eight sisters. Our parents died when I was very young. My grandmother looked after us with the money she made making and selling hoppers. I walked on the streets selling hoppers. I studied up to O/L class. I dropped out of school because of poverty and because I had to look after my younger siblings. All my brothers and sisters went up to $O / L$ or $A / L$. All of them, except one brother who died, are now doing well either here in Sri Lanka or abroad. Married at 21, I was 27 when my husband was killed. My daughter was one year old and I was pregnant with my son. Nobody was there to help me earn money. My siblings helped me make wadai and sell. I have achieved a lot thereafter. I managed to give 10 sovereign pounds each as dowry for my sisters; educated my children; built this house into its current structure; the villagers see me as an important character.

- Thushita, 51, Point Pedro -

Loss of intimate family members due to war, as in the case of Thushita not only affected their financial capital through loss of livelihoods but also their social capital (Lakshman, 2018). According to Coleman (1988) and Portes (1998), family background of a person forms an important part of that person's social capital. Lumsden (1994), for example, stated the role of the significant others (parents and home environment) in students' academic performance as a main factor which shapes the initial constellation of students' attitudes they develop toward learning. He stressed that "When children are raised in a home that nurtures a sense of self-worth, competence, autonomy, and self-efficacy, they will be more apt to accept the risks inherent in learning." (p. 2).

\section{Support mechanisms available to remain in school}

Several support mechanisms, from external as well as internal sources, were made available to victims of war and tsunami in order to help them remain in school. The external mechanisms were largely in the form of financial and material aid coming from the Government, NGOs and INGOs. Most of the support rendered has been to ensure the general wellbeing of the victims which may have indirectly contributed towards retaining children's interest in education if not in school.

There were also limited counselling services provided for children to help them overcome the psychological trauma of war. According to the zonal 
education directors, a counsellor has been appointed for every school with a student population over 300 . However, interviews with villagers confirmed that this was not the case in practice.

Internal sources of support included community and family level support that was the most useful in keeping children in school.

\section{Support from the community}

As explained by the group of social workers, community-level support was extremely instrumental in keeping children in school. Mary is a war widow living in an IDP camp with five children and no stable income. Her electricity bill got accumulated to an amount that she could not afford and currently she lives without electricity in her home.

I cannot afford to pay the overdue amount. My neighbour put up a bulb right over our fence. That is the only light we have. Now my children sit under that light and study.

- Mary, 43, Chunnagam camp -

War victims, particularly war-widows, were also supported by the community to develop means of livelihood. Thushita (see above) is one such female entrepreneur who helps 13 war-widows make an income for themselves. Improved family income levels due to this kind of livelihood opportunities not only helped keep children in school but also improved the social stature of women. Mothers' desire to educate their daughters is probably a result of this heightened social stature created by their improved income levels. Improved social stature and income levels of these women are likely to improve their social capital in the long run leading to improved educational opportunities for their children (Lakshman, 2018).

Community support was useful in helping resettled schools reach its aspired standards. Today, Nadeshwara College administration is worried that they may not get adequate numbers of students to continue the school. In order to solve this problem, the school and the past pupils are actively involved in providing material support to children as an incentive to come to school. Thanks to the school's 100 year old history and the caliber of children admitted to the school in the past, the school is generously funded by past pupils here and in foreign countries. Additionally, the past pupils provide funds for paying volunteer teachers who teach in the school. A comparison of the current plight of Nadeswara College and the school in Madhagal explains the significance of community support for re-establishing resettled schools. Even though the school in Madhagal is also over 100 years old, the past pupils are not as influential as in the case of Nadeshwara College. Historically the school has been attended by deprived low-caste children whereas Nadeshwara College has had very high class and elitist students. Therefore, improving the quality of the school in Madhagal is seen as a problem. 
Anyone who can find a way to leave the village and find a school in the city would not hesitate to do that. Those who left the village because of the war or the tsunami never returned. So it is the most desperate and deprived individuals that are still left in the village and attending the village school. They cannot do much to help the school.

- Principal, Madhagal School -

For individuals who were displaced to IDP camps, there have been formal and informal arrangements for teaching and learning to take place. Informally, community members who have completed their O/Ls and/or A/Ls volunteered to teach younger children. In some cases these older students themselves were IDPs in the same camp. Formal support was provided by Government teachers who came into camps and taught students (Selvi, 40, Sinnathottam village). Additionally, the tuition classes offered by the Church at subsidiary fees and the free extra lessons offered by school was also helpful in this venture.

Community level support has been very instrumental in improving social capital of individuals which would eventually contribute to the improvement of social capital of the entire community.

\section{Family support}

As confirmed by previous researchers, the significance of family background and support for children's academic achievements is confirmed. In fact, family background and support seems the most instrumental in retaining children in school during and after war. The strength of the family seems to overpower all other forms of external support received by children to engage in education, even under conditions of war. Family was observed to be influential on children's academic achievements in broadly two ways.

Firstly, older siblings were seen sacrificing their educational opportunities to provide the same for their younger siblings. Older siblings dropping out of school to help improve family income was useful for the education of younger siblings. Revathy (44) assured that her daughters' educational expenses were solely borne by her sons who dropped out of school early to support the family income. In other families older siblings dropped out of school to babysit their younger siblings while parents were away at work.

Secondly, strength of relationships between family members was observed to be influential in determining children's academic achievements. Here, the most vital factor pertaining to family background was that the nuclear family was intact without any deaths caused by war or other factors such as the 2004 tsunami or disease. Children coming from families where both parents were alive and in relatively good health with some kind of a stable income seemed to do well in education compared to other families who have 
lost family members. For example, Malar, 39 years, lives in an IDP camp with her husband and five children. Her first child is awaiting university entrance and her second child who has got through his $\mathrm{O} / \mathrm{Ls}$ will be taking $\mathrm{A} / \mathrm{Ls}$ in 2018. Remaining three children are attending leading schools in the area and Malar is confident that all three of them will get through their O/Ls without much difficulty. Malar's husband, educated up to Grade 10, is the president of their camp and therefore a respected member of the community. Even though Malar has only studied up to Grade 4, her commitment towards her children's education seemed very strong.

Life is tough for us. But I will provide anything that my children need for their education. My husband doesn't drink or smoke. There is no violence at home. We do everything to give our children a peaceful environment for studying at home. If there is money problem at home, I will get a loan and provide things necessary for my children's education.

- Malar, 39, IDP camp-

Research on parenting also has shown that parent's education is related to a warm, social climate in the home. Gottfried et al. (2004) found that both mothers' education and family income were important predictors of the physical environment and learning experiences in the home but that mothers' education alone was predictive of parental warmth.

Pavithra, a mother of 5, has a similar story to tell. She has a shop in the IDP camp and her husband engages in labour work. Except her eldest son, all her children are doing well in terms of educational achievements.

Only my first child dropped out of school without taking his O/Ls (tears in eyes). He himself gave up school and started working as a mason because he wanted to support the family economy. Second son will be completing his degree this year and the fourth daughter just started her BA. $3^{\text {rd }}$ daughter got through all subjects at A/Ls but could not get university entrance. Youngest son will be taking his $\mathrm{O} / \mathrm{L}$ s this year. We don't have a TV. My children are not sent for tuition for O/Ls only for A/Ls. My husband doesn't drink or smoke.

- Pavithra, 49, IDP camp -

Three other women interviewed in the camp claimed that their husbands did not smoke or drink alcohol. The children in these families were successful in education compared to children in other families. The general view in the community was that if fathers smoke and/or drink it becomes a reason for domestic violence in the house which ultimately results in traumatized children who in turn would find it difficult to excel in their school work. These families also were comparatively financially well off either due to income generated by the family or NGO and other sources of support. In many of these families, children had completed other diplomas such as IT 
courses, English courses and beauty culture courses in addition to school and/or university.

Saradha, a 23 year old University student, lives in an IDP camp with her mother and two siblings. She has lost her father at the age of six and her mother has looked after the family with her income as a seamstress. Her younger brother has got through his $\mathrm{O} / \mathrm{Ls}$ but he has dropped out of school and started work as a three-wheel driver in order to help the family financially. According to the president of the Camp, Saradha's mother and other widows have received extra help from several NGOs and foreigners. The family receives Rs. 15000 from the church even now. Saradha's younger sister is studying for her $\mathrm{A} / \mathrm{Ls}$ and is hopeful of getting through to the university. Saradha's house was unlike any house in the camp. It was very neat and well kept; a sign of a committed housewife and a supportive family. Though the researchers did not get an opportunity to meet the mother, the house and the family bonds seemed conducive towards academic achievement.

During the time when I did $O / L$ and $A / L$, I used to sleep at 6 p.m. and wake up at 2 p.m. That was the only way to avoid the loud neighbourhood in the camp during the day. Mother provided everything we needed to study.

- Saradha, 23, IDP camp -

These findings confirm the strength of intimate family relationships in determining a person's social capital even under conditions of war (Coleman, 1988; Lakshman, 2018).

\section{Conclusion}

Thirty years of war in Sri Lanka has caused colossal damage to infrastructure and human life in the region studied creating various kinds of hindrances on children's education. Infrastructural damage resulted in temporary closure of schools and relocation of some schools causing physical barriers towards going to school. Displacement, loss of livelihoods and death of intimate family members disarrayed the social life in the region also creating educational difficulties for children. Even though the region recovered from infrastructural damages eventually the psychological trauma caused by the latter was a bigger challenge to overcome.

Financial aid from the Government, NGOs and INGOs was the commonest means that helped the people overcome difficulties of financial capital. However, the strongest and the most instrumental type of support has come from within the community and the family. The study confirms the strength of the family and other intimate relationships as the strongest source of social capital for educational support during and after times of war.

The need to strengthen the well-being of families by way of enhanced livelihoods and empowering women is recommended in order to strengthen 
this social capital base. The need for stronger counselling support for children is also emphasized.

\section{References:}

1. Akresh, R., Verwimp, P., \& Bundervoet, T. (2011). Civil War, Crop Failure, and Child Stunting in Rwanda. Economic Development and Cultural Change, 59(4), 777-810.

2. Al-Khalidi, A., Hoffman, S. and Tanner, V. (2007). 'Iraqi Refugees in the Syrian Arab Republic: A Field-Based Snapshot'. The Brookings Institution/University of Bern Project on Internal Displacement.

3. Amirthalingam, K. \& Lakshman, R.W.D. (2012). Impact of Displacement on Women and Female-headed Households: A Mixed Method Analysis with a Microeconomic Touch. Journal of Refugee Studies, 26(1), 26-46.

4. Baker, V.J. (1988). The Blackboard in the Jungle: Formal Education in Disadvantaged Rural Areas. A Sri Lankan Case. Delft: Eburon.

5. Boyden, J. (2003). Children under Fire: Challenging Assumptions about Children's Resilience. Children, Youth and Environments, 13(1), $1-29$.

6. Carillo, A.C. (2009), 'Internal Displacement in Colombia: Humanitarian, Economic and Social Consequences in Urban Settings and Current Challenges' International Review of the Red Cross, 91, 875, 531-536.

7. Carpenter, R.C. (2005). Women, Children and Other Vulnerable Groups: Gender, Strategic Frames, and the Protection of Civilians as a Transnational Issue. International Studies Quarterly, 49(2): 295-394.

8. Carpenter, R.C. (2006). Innocent Women and Children: Gender, Norms and the Protection of Civilians. Aldershot: Ashgate.

9. Coleman, J.S. (1988). Social Capital in the Creation of Human Capital. American Journal of Sociology, 94, 94-120.

10. Ensor, M.O. (2010), 'Education and self-reliance in Egypt' Adapting to Urban Displacement- Forced Migration Review, 34, 25.

11. Gottfried, E.A., Fleming, S.J. Gottfried, W.A. (1994). Role of Parental Motivational Practices in Children's Academic Intrinsic Motivation and Achievement. Journal of Educational Psychology, 86(1), 104-113.

12. Gunatilaka, R. and Vithanagama, R. (2018). Women's Labour Market Outcomes and Livelihood Interventions in Sri Lanka's North after the War. Colombo: International Centre of Ethnic Studies.

13. Hick, S. (2001). The Political Economy of War-Affected Children. The Annals of the American Academy of Political and Social Science, 575, 106-121. 
14. Jayatilaka, D., \& Amirthalingam, K. (2015). The impact of displacement on dowries in Sri Lanka. The Brooking Institute-LSE.

15. Jordan, N.C., Kaplan, D. Oláh, L.N. and Locuniak, N. (2006), "Number Sense Growth in Kindergarten: A Longitudinal Investigation of Children at Risk for Mathematics Difficulties, Child Development, 77, 1, 153-175.

16. Kottegoda, S., Samuel, K., \& Emmanuel, S. (2008). Reproductive health concerns in six conflict-affected areas of Sri Lanka. Reproductive health matters, 16(31), 75-82.

17. Lai, B., \& Clayton, T. (2007). The Effect of Civil War on Education. Journal of Peace Research, 44, 277-292.

18. Lall, A. (2016). "Don't tell them where we live"-Caste and access to education in northern Sri Lanka, Colombo: CEPA.

19. Lakshman, I.M. (2018). Impact of intimate relationships on livelihood activities of women affected by war in Northern Sri Lanka. Colombo: International Centre of Ethnic Studies.

20. Little, A.W. (1999). Labouring to Learn: towards a political economy of plantations, people and education in Sri Lanka. London: Macmillan Press

21. Lumsden, L.S. (1994). Student Motivation to Learn. ERIC Clearinghouse on Educational Management Eugene.

22. McKay, S. (2004). Where are the Girls? Girls in Fighting Forces in North- ern Uganda, Sierre Leone and Mozambique: Their Lives During and After War, Rights \& Democracy. 1st ed. Montreal: International Centre for Human Rights and Democratic Development.

23. Mourtada, R., Schlecht, J., \& DeJong, J. (2017). A qualitative study exploring child marriage practices among Syrian conflict-affected populations in Lebanon. Conflict and health, 11(1), 53-65.

24. Onyango, G., Atyam, A., Arwai, C. \& Acan, J. (2005). Girl Mothers of Northern Uganda. Bellagio, Conference on Girl Mothers in Fighting Forces and their Post-War Reintegration in Southern and Western Africa.

25. Portes, A. (1998). Social capital: Its origins and applications in modern sociology. Annual review of sociology, 24(1), 1-24.

26. Reay, D. (2006), 'The Zombie Stalking English Schools: Social Class and Educational Inequality', British Journal of Educational Studies, 54, 3, 288-307.

27. Schlecht, J., Rowley, E., \& Babirye, J. (2013). Early relationships and marriage in conflict and post-conflict settings: vulnerability of youth in Uganda. Reproductive Health Matters, 21(41), 234-242.

28. Shizha, E. (2017). The Impact of Civil Conflict or War on Children's Right to Education in Africa. In Security, Education and Development 
in Contemporary Africa. Izarali, M.R., Masakure, O., \& Shizha, E. (eds). New York: Routledge, pp. 121-137.

29. Sivakumar, C. (1989). Social Origins of the Sri Lankan Tamils' Militant Movement. Sociological Bulletin, 38(1), 119-139.

30. Somasundaram, D. (1998). Scarred minds: The psychological impact of war on Sri Lankan Tamils. Sage Publications.

31. Spencer, J. (2002). Sri Lanka: History and the roots of conflict. Routledge.

32. Stinebrickner, R. \& Stinebrickner, T.R. (2003), 'Understanding Educational Outcomes of Students from Low-Income Families: Evidence from a Liberal Arts College with a Full Tuition Subsidy Program', The Journal of Human Resources, 38, 3, 591-617.

33. Tolin, D. \& Foa, E. (2006). Sex Differences in Trauma and PostTraumatic Stress Disorder: A Quantitative Review of 25 Years of Research. Psychological Bulletin, 132(6), pp. 959-992.

34. van Wessel, M. \& van Hirtum, R. (2013). Schools as Tactical Targets in Conflict: What the Case of Nepal Can Teach Us. Comparative Education Research, 57(1), pp 1-21.

35. Willis, P. (1977). Learning to Labour: How Working Class Kids get a Working Class Job. New York: Columbia University Press. 